\title{
JENIS TANAMAN INANG DAN MASA INKUBASI PATOGEN BOTRYODIPLODIA THEOBROMAE PAT. PENYEBAB PENYAKIT KULIT DIPLODIA PADA JERUK
}

\author{
Salamiah $^{1}$, Badruzsaufari $^{2}$, dan Muhammad Arsyad ${ }^{2}$
}

\begin{abstract}
Alternative hosts and Incubation period of Botryodiplodia theobromae the causal of diplodia bark diseases on citrus. Citrus is one of the important horticulture commodities in South Kalimantan. Citrus growers in the region encounter diplodia disease caused by a genus of Botryodiplodia. There is no single method practiced today proved to be effective control for the disease. Insufficient information of the pathogen life cycle is considered to contribute in the failure of disease management. Information of the alternative hosts and incubation period of the pathogens is very crucial in the diseases management. The experiments were carried out at the Laboratory of Plant Diseases and at a Glass House of the Department of Plant Pests and Diseases of the Faculty of Agriculture, Lambung Mangkurat University in Banjarbaru from March - October 2006. The experiments were conducted in three phases, i.e. (1) identification of pathogen, (2) the study of alternative hosts, and (3) the study of incubation periods of the pathogen in the test plants. Results showed that the diplodia disease of citrus "Siam Banjar" was caused by a fungus of the genus Botryodiplodia theobromae. The pathogen can also infected chasew and avocado plants. The Incubation periods of the pathogen in citrus, chasew, and avocado were 64, 39 and 39 days, respectively.
\end{abstract}

Key words : Citrus "Siam Banjar", Botryodiplodia theobromae, diplodia bark diseases, alternative hosts, incubation period

\section{PENDAHULUAN}

Jeruk merupakan salah satu komoditas hortikultura yang mendapat prioritas untuk dikembangkan di Kalimantan Selatan. Jeruk Sungai Madang merupakan cikal bakal perkembangan jeruk di Kalimanatan, yang sekarang telah menjadi varietas jeruk siam nasional yang diberi nama jeruk Siam Banjar. Jeruk Siam Banjar telah berhasil memperoleh juara I kontes jeruk siam di Ekspose Nasional Teknologi Pertanian Lahan Pasang Surut 2003, juara II Kontes Jeruk Siam Tingkat Nasional 2004 di Surabaya (Anonim, 2005).

Luas pertanaman dan produksi jeruk di Kalimantan Selatan terus mengalami peningkatan, namun produktivitas mengalami penurunan. Rendahnya produktivitas dan terjadinya penurunan produktivitas jeruk ini antara lain disebabkan oleh teknik budidaya tanaman yang umumnya masih kurang memadai, sehingga mendorong timbulnya berbagai gangguan pertumbuhan tanaman. Salah satu gangguan yang mengakibatkan hasil cukup rendah pada pertanaman jeruk adalah serangan Organisme Pengganggu Tumbuhan (OPT).
Di antara penyakit tanaman pada tanaman jeruk di Kalimantan Selatan, penyakit kulit diplodia adalah penyakit yang paling ditakuti oleh petani jeruk (Balai Proteksi Tanaman Pangan dan Hortikultura, Kalimantan Selatan, 2003), karena serangannya dapat mengakibatkan kematian ranting, cabang, batang tanaman, bahkan menyebabkan kematian tanaman (Anonim, 2002; Setiawan, 1993). Jumlah tanaman jeruk terserang diplodia di Kalimantan Selatan sebanyak 825.318 pohon (53,9 \% dari total tanaman jeruk) (Balai Proteksi Tanaman Pangan dan Hortikultura, Kalimantan Selatan, 2003).

Penyakit diplodia disebabkan oleh cendawan Botryodiplodia theobromae Pat. B. theobromae adalah cendawan polifag, yang dapat menyerang bermacam-macam tumbuhan, sehingga sumber infeksi akan selalu ada (Semangun, 2000). Penyakit ini tersebar disentra-sentra pengembangan jeruk di Kalimantan Selatan, seperti Kabupaten Barito Kuala, Banjar, Banjarmasin, Banjarbaru, Tapin, Hulu Sungai Selatan, Hulu Sungai Utara, Hulu Sungai Tengah, Tabalong, Tanah Laut dan Kotabaru (Balai Proteksi Tanaman Pangan dan Hortikultura, Kalimantan Selatan, 2003).

\footnotetext{
${ }^{1}$ Jurusan Hama dan Penyakit Tumbuhan, Fakultas Pertanian, Universitas Lambung Mangkurat, Jl. Jend. A. Yani Kotak Pos 1028, Banjarbaru, Tel \& Fax. 0511-4777392, e-mail: salamiah_amsya@yahoo.com

2 Program Studi Biologi Fakultas MIPA, Universitas Lambung Mangkurat, Jl. Jend. A. Yani, Banjarbaru
} 
Pengendalian yang pernah dilakukan antara lain dengan menggunakan mikroorganisme antagonis seperti Trichoderma harzianum, namun tidak efektif menekan pertumbuhan $B$. theobromae penyebab penyakit kulit diplodia di lapangan (Salamiah dan Rahmah, 2004). Hasil yang sama diperoleh Salamiah dan Melanie (2004) bahwa pestisida botanis seperti bawang merah, bawang putih, dan daun mimba juga tidak efektif mengendalikan patogen tersebut. Hal ini diduga karena daur hidup patogen belum diketahui dengan pasti sehingga tindakan pengendalian masih kurang tepat sasaran. Pemahaman yang baik terhadap patogen terutama tentang jenis tanaman inang dan masa inkubasi patogen diharapkan dapat membantu mengendalikan penyakit ini.

Keberhasilan pengendalian penyakit tanaman ini salah satunya ditentukan oleh pengetahuan tentang inang apa saja yang digunakan oleh patogen ini sebagai tempat bertahan karena pengendalian yang ditujukan kepada patogen di tanaman inang utama saja masih belum cukup.

Penelitian ini bertujuan untuk mengetahui inang alternatif dan masa inkubasi patogen $B$. theobromae (penyebab penyakit kulit diplodia) pada jeruk Siam Banjar (Citrus sinensis L. Osbeck). Hasil penelitian ini diharapkan dapat memberikan informasi yang dapat digunakan dalam pengendalian terpadu penyakit kulit diplodia pada jeruk.

\section{METODE PENELITIAN}

Penelitian ini dilaksanakan pada bulan Maret Oktober 2006 di Laboratorium Penyakit Tumbuhan dan Rumah Kaca Jurusan Hama dan Penyakit Tumbuhan, Fakultas Pertanian Universitas Lambung Mangkurat.

Isolasi patogen dari tanaman sakit. Patogen diisolasi dengan cara memotong bagian tanaman yang terserang penyakit kulit diplodia, kemudian dicelupkan dalam $\mathrm{NaClO}$ 1\% selama 10 menit. Potongan batang, cabang atau ranting kemudian dicuci dengan air steril sebanyak 3 kali lalu dikeringkan dengan kertas hisap steril dalam cawan petri. Setelah kering, kulit batang jeruk yang memperlihatkan gejala serangan patogen penyebab penyakit kulit diplodia dipotong kecil-kecil sebesar $1 \times 3 \mathrm{~cm}$, potongan tersebut dimasukkan ke dalam moist chamber berisi kertas tissue steril yang telah dibasahi. Potongan tanaman yang bergejala diletakkan di atas objek gelas atau pengganjal lainnya untuk menghindarkan kontak langsung dengan kertas tissue basah.

Isolat patogen dalam chamber ini kemudian diinkubasikan pada suhu kamar selama satu minggu sampai terjadi sporulasi pada permukaan batang, cabang atau ranting tanaman. Kelembaban chamber harus selalu dipelihara dengan selalu menambahkan sejumlah air steril ke tissue di dalam chamber.

Untuk uji patogenisitas, diperlukan isolat patogen dalam bentuk spora yang akan dijadikan suspensi spora. Untuk keperluan ini isolasi patogen dilakukan sebagai berikut: Isolasi patogen dari tanaman bergejala dengan menggunakan medium PDA (Potato Dextrose Agar) dilakukan dengan cara memotong bagian tanaman yang menunjukkan gejala awal dengan ukuran $0,5 \times 0,5 \mathrm{~cm}$. Potongan tanaman ini dicelupkan ke dalam alkohol 70\% atau $\mathrm{NaClO} 1 \%$ selama satu menit, dan dicuci dengan air steril sebanyak tiga kali. Bagian antara jaringan cabang pohon dan bagian jaringan yang terserang yang memperlihatkan gejala aktif dipotong. Potongan kecil tanaman tersebut diletakkan pada media PDA dalam cawan petri guna memperoleh isolat murni cendawan patogen. Koloni cendawan yang tumbuh pada media dimurnikan sehingga diperoleh kultur murni (pureculture) dan selanjutnya diremajakan dengan cara menumbuhkan pada media miring (slant agar) sehingga siap untuk dipergunakan sebagai sumber inokulum.

Identifikasi patogen. Gejala penyakit kulit diplodia yang ditemukan di Kalimantan Selatan ada dua jenis yakni diplodia basah dan diplodia kering. Isolat yang dipergunakan dalam penelitian ini diidentifikasi terlebih dahulu untuk meyakinkan bahwa patogen yang dipergunakan adalah $B$. theobromae penyebab penyakit kulit diplodia pada jeruk. Identifikasi dilakukan dengan mempergunakan kunci identifikasi Illustrated Genera of Imperfect Fungi (Barnet \& Hunter, 1972).

Masa inkubasi patogen pada tanaman. Lamanya masa inkubasi patogen dalam tanaman inang diamati dengan jalan menginokulasikan patogen ke tanaman jeruk, kemudian mengamati waktu mulai munculnya gejala penyakit kulit diplodia. Inokulasi dilakukan dengan jalan penempelan. Batang bibit jeruk berumur 
6 bulan dalam polybag terlebih dahulu dibersihkan dengan air bersih kemudian disemprot dengan alkohol $70 \%$. Setelah itu batang dilukai dengan pisau steril kemudian potongan batang yang berisi inokulum patogen diselipkan. Untuk menjamin potongan tersebut tidak lepas dari batang jeruk, potongan kulit batang yang berisi inokulum dilekatkan dengan memberi selotip pada kedua bagian ujungnya. Kelembaban di sekitar tempat inokulasi ini dipelihara dengan menyemprotkan air steril. Pemeliharaan ini dilakukan sampai timbul gejala penyakit.

Untuk mengetahui jenis tanaman yang dapat menjadi inang alternatif maka dilakukan uji patogenisitas terhadap tanaman yang mewakili tanaman monokotil dan dikotil, yakni kelapa, nangka, jambu monyet, alpukat, belimbing, pepaya, dan karet. Tanaman tesebut dipilih dari tanaman yang selalu ada di sekitar sentra pertanaman jeruk yang menjadi lokasi pengambilan sampel tanaman sakit. Uji patogenisitas dilakukan dengan jalan menginokulasikan suspensi spora patogen ke tanaman yang diduga sebagai inang alternatif serta tanaman jeruk Siam Banjar. Suspensi spora dengan kerapatan $1 \times 10^{7}$ spora/ml masingmasing sebanyak $1 \mathrm{ml}$, diinokulasikan dengan jalan mengoleskan suspensi spora ke bagian tanaman (daun dan batang/ranting atau pelepah daun yang telah dipilih) yang sebelumnya telah diberi goresan kecil untuk membantu proses masuknya patogen ke dalam bagian tanaman yang diuji. Untuk menjaga kelembaban, di sekitar tanaman diberi pengembunan dengan jalan menyemprotkan air steril dengan hand sprayer.

Percobaan inkubasi ini diulang sebanyak 3 kali, masing-masing terdiri atas satu tanaman uji. Selain itu, kontrol perlakuan dilaksanakan terhadap tanaman yang diperlakukan serupa dengan tanaman uji tetapi tidak diinokulasi dengan isolat patogen.

Pengamatan. Semua gejala yang menunjukkan penyakit diplodia dicatat sejak mulai teramatinya gejala tersebut. Bentuk gejala berbeda-beda pada setiap tanaman uji. Untuk tanaman jeruk gejala berupa retaknya bagian permukaan batang yang diikuti dengan keluarnya gom/blendok berwarna coklat keemasan. Pada musim penghujan, pada permukaan batang yang retak keluar buih berwarna putih; pada jambu monyet berupa cairan yang mulamula lembek kemudian mengeras membentuk gum atau gumpalan yang berwarna coklat; sedangkan pada alpukat, gejala serangan mirip dengan gejala pada jeruk yakni batang yang mengeluarkan gom berwarna coklat keemasan. Masa inkubasi dihitung berdasarkan waktu hari antara saat inokulasi dengan pertamakali munculnya gejala penyakit pada masing-masing tanaman. Patogen diplodia diisolasi kembali (reisolasi) dari tanaman yang menunjukkan gejala. Selanjutnya dilakukan identifikasi terhadap patogen dengan menggunakan kunci determinsasi yang sama seperti sebelumnya.

\section{HASIL DAN PEMBAHASAN}

Identifikasi patogen. Dari hasil identifikasi patogen yang diisolasi dari tanaman sakit yang diinokulasi dengan patogen $B$. theobromae, didapatkan bentukbentuk konidia yang sangat mirip seperti yang disajikan pada Gambar 2 untuk konidia B. theobromae pada tanaman Jeruk, Gambar 4 untuk konidia $B$. theobromae pada tanaman jambu monyet, dan Gambar 6 untuk konidia B. theobromae pada tanaman alpukat.

Uji B. theobromae pada tanaman jeruk dan tanaman inang lainnya dan masa inkubasinya. Delapan tanaman yang diinokulasi dengan isolat B. theobromae memperlihatkan respon yang berbedabeda terhadap patogen tersebut (Tabel 1). Selama lima bulan pengamatan, hanya tiga tanaman yakni jeruk, jambu monyet, dan alpukat yang menunjukkan gejala terserang penyakit diplodia. Tanaman jambu monyet dan alpukat mulai menunjukkan gejala pada hari ke 39 setelah inokulasi sedangkan pada tanaman jeruk pada hari ke 64 setelah inokulasi. 
Tabel 1. Uji Botryodiplodia theobromae pada tanaman jeruk dan tanaman inang lainnya dan masa inkubasinya

\begin{tabular}{lcc}
\hline \multicolumn{1}{c}{ Tanaman Uji } & $\begin{array}{c}\text { Uji terhadap } \\
\text { B. theobromae }\end{array}$ & Masa Inkubasi \\
\hline Jeruk & +++ & 64 hari \\
Kontrol & -- & - \\
Kelapa & - & - \\
Kontrol & - & - \\
Nangka & - & - \\
Kontrol & - & - \\
Jambu monyet & ++ & 39 hari \\
Kontrol & -- & - \\
Alpukat & ++ & 39 hari \\
Kontrol & - & - \\
Belimbing & - & - \\
Kontrol & - & - \\
Pepaya & - & - \\
Kontrol & - & - \\
Karet & - & - \\
Kontrol & - & - \\
Keterangan : kontrol = tidak diinokulasi dengan patogen; - = Tidak ada gejala; + = Gejala penyakit diplodia
\end{tabular}

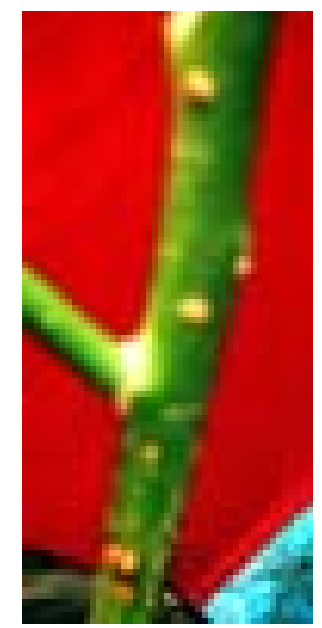

Gambar 1. Gejala Botryodiplodia theobromae pada tanaman jeruk.

Gejala serangan penyakit Diplodia dan isolasi Botryodiplodia theobromae pada tanaman jeruk yang diinokulasi dengan isolat $B$. Theobromae. Tanaman jeruk yang diinokulasi dengan isolat B. theobromae yang diperoleh dari lapangan memperlihatkan adanya luka-luka atau jalur-jalur yang sempit sehingga pada kulit terjadi luka-luka yang tidak teratur yang luas tapi dangkal dan batang yang terserang berwarna hitam (Gambar 1). Ciri-ciri tadi teramati pada ketiga tanaman uji dan menunjukkan bahwa isolat yang diberikan mampu menimbulkan penyakit diplodia. Spora yang diisolasi dari bagian tanaman jeruk yang menunjukkan gejala penyakit diplodia disajikan pada Gambar 2. Hasil serupa juga diperoleh dari dua tanaman jeruk yang terserang penyakit itu. Spora tersebut mempunyai bentuk bulat lonjong dan bersekat. Bentuk spora ini merupakan ciri khas dari patogen tersebut. 


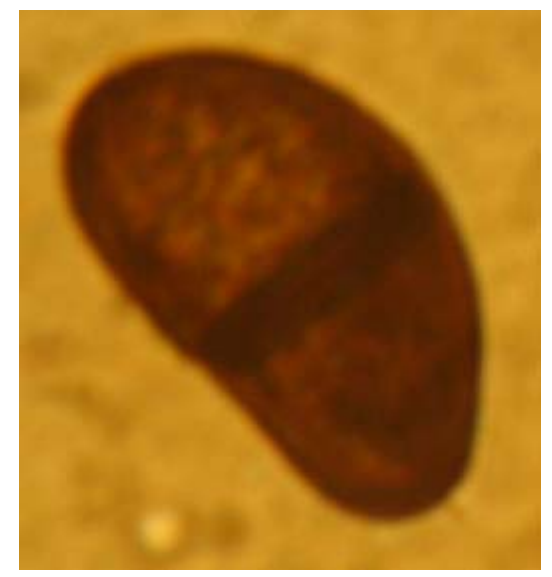

Gambar 2. Konidia Botryodiplodia theobromae pada tanaman Jeruk.

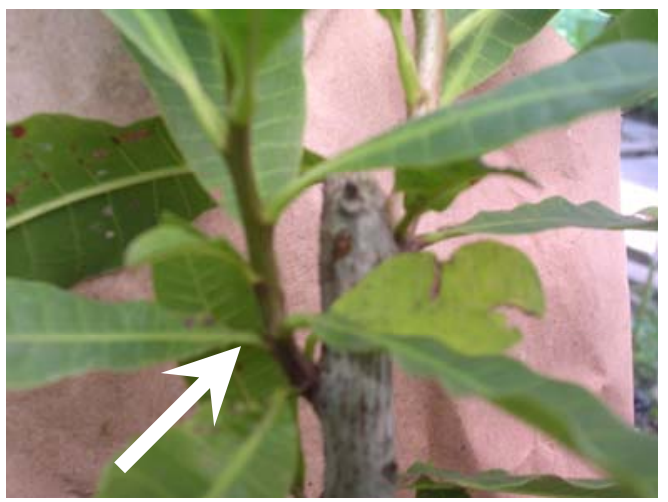

Gambar 3. Gejala Botryodiplodia theobromae pada tanaman jambu monyet

Gejala serangan penyakit Diplodia dan isolasi $B$. theobromae pada tanaman jambu monyet yang diinokulasi dengan isolat $B$. theobromae. Penyakit kulit diplodia pada tanaman jambu monyet yang diinokulasi dengan isolat $B$. theobromae yang diperoleh dari lapangan memperlihatkan gejala berupa cairan yang mula-mula lembek kemudian mengeras membentuk gom/gumpalan yang berwarna coklat (Gambar 3). Ciri-ciri tadi teramati pada ketiga tanaman uji. Spora yang diisolasi dari bagian tanaman jambu monyet yang menunjukkan gejala penyakit kulit diplodia disajikan pada Gambar 4. Hasil serupa juga diperoleh dari dua tanaman jambu monyet yang terserang penyakit tersebut.
Gejala serangan penyakit Diplodia dan isolasi $B$. theobromae pada tanaman alpukat yang diinokulasi dengan isolat $B$. theobromae. Tanaman alpukat yang diinokulasi dengan isolat $B$. theobromae yang diperoleh dari lapangan menunjukkan gejala berupa bintik-bintik hitam pada batangnya dan rusaknya batang di dekat titik inokulasi (Gambar 5). Ciri-ciri tadi hanya teramati pada dua ulangan, satu ulangan lainnya tidak memperlihatkan gejala sakit. Spora yang diisolasi dari bagian tanaman alpukat yang menunjukkan gejala penyakit diplodia disajikan pada Gambar 6. Hasil serupa juga diperoleh dari tanaman uji yang terserang penyakit diplodia. 


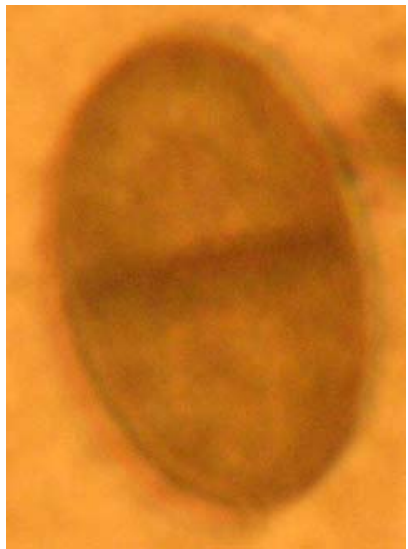

Gambar 4. Konidia Botryodiplodia theobromae pada tanaman jambu monyet.

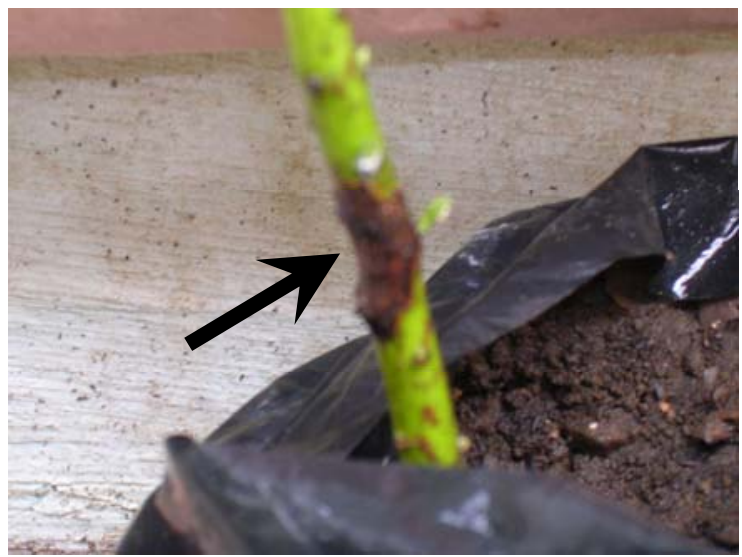

Gambar 5. Gejala Botryodiplodia theobromae pada tanaman alpukat.

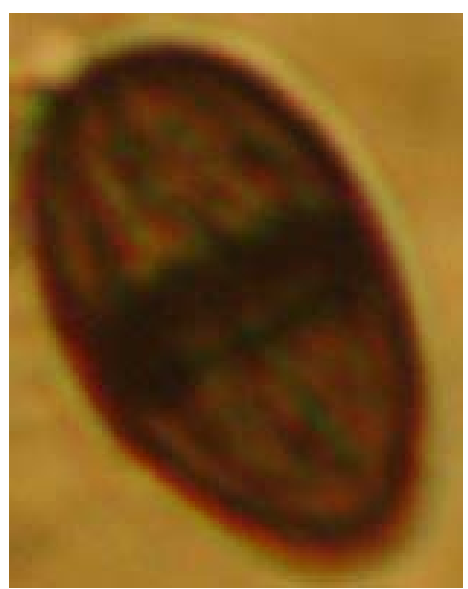

Gambar 6. Konidia Botryodiplodia theobromae pada tanaman alpukat. 
Diantara delapan jenis tanaman yang digunakan dalam penelitian ini, ada tiga tanaman yang dapat diserang oleh $B$. theobromae yaitu jeruk, jambu monyet dan alpukat, sedangkan kelapa, karet, nangka, belimbing dan pepaya tidak diserang patogen tersebut. Ketiga tanaman yang terkena diplodia ini, menunjukkan gejala yang berbeda-beda. Pada jeruk gejala yang tampak berupa adanya jalur-jalur yang sempit dan terus berkembang sehingga pada kulit terjadi luka yang tidak teratur, luas tapi dangkal dan batang yang terserang berwarna kehitam-hitaman. Gejala tersebut terdapat pada ketiga tanaman uji. Gejala penyakit diplodia pada jambu monyet berupa cairan yang mula-mula lembek kemudian mengeras membentuk gum atau gumpalan yang berwarna coklat. Seperti pada tanaman jeruk, gejala pada jambu monyet ini juga terdapat pada ketiga tanaman uji lainnya sedangkan tanaman kontrol (tidak diberi isolat $B$. theobromae) baik jeruk maupun jambu monyet, pada batangnya tidak menunjukkan gejala apa-apa. Dalam penelitian ini, dilakukan isolasi kembali dan identifikasi terhadap patogen pada kedelapan tanaman uji, termasuk kontrol. B. theobromae tidak ditemukan pada semua tanaman kontrol. Hal ini menunjukkan bahwa semua tanaman kontrol tidak terserang $B$. theobromae sehingga gejala tidak ada. Dilihat dari masa inkubasinya, terdapat perbedaan antara tanaman jeruk dengan tanaman jambu monyet, yaitu masing-masing 64 hari dan 39 hari. Diplodia menyerang jambu monyet di Brazil (Ohler, 1979), India, Malaysia, dan Senegal, Nigeria (Olunloyo \& Esuruoso, 1975). Di Nigeria, gejala diplodia juga ditemukan pada buah dan tangkai bunga jambu monyet (Olunloyo \& Esuruoso, 1975). Patogen ini juga menyerang jambu monyet di Indonesia seperti di Cikampek dan Bali. Gejala penyakit diplodia pada tanaman jambu monyet yang sudah berproduksi di lapangan dapat ditemukan pada pangkal batang, cabang, ranting, pucuk dan tangkai bunga (Sitepu \& Adhi, 1990). Gejala berupa keluarnya cairan yang mula-mula lembek, kemudian mengeras membentuk gum yang berwarna coklat, hitam atau putih.

Bagian pucuk atau daun bibit jambu monyet yang diinokulasi dengan cendawan B. theobromae, mulai menunjukkan gejala penyakit pada dua hari setelah inokulasi, yaitu berupa bercak hitam pada daerah inokulasi. Bercak kemudian meluas ke bagian tangkai dan helai daun yang terdekat sehingga tulang daun menjadi hitam, layu dan kadang-kadang rontok. Penyebaran infeksi pada pucuk dan batang utama mengakibatkan seluruh tanaman yang diinokulasi menghitam dan mati sampai pada pangkal batang. Hasil pengujian patogenisitas menunjukkan bahwa isolat $B$. theobromae Pat. secara konsisten menyebabkan gejala penyakit pada bibit jambu monyet (Supriadi et al., 1994).

Secara umum gejala yang teramati pada penelitian ini adalah kulit tanaman yang terserang mengering dan terkelupas. Sering terjadi penyakit berkembang terus hingga pada kulit terjadi luka yang tidak teratur, tetapi kadang-kadang serangan terbatas pada jalur yang sempit dan memanjang. Pada serangan lebih lanjut, gejala melingkari batang/cabang dan dapat menyebabkan kematian tanaman. Cendawan berkembang diantara kulit dan kayu, dan merusak kambium tanaman. Kayu yang mati berwarna hijau kebiruan sampai hitam.

Telah dilaporkan bahwa diplodia juga menyerang alpukat di Thailand dan Filipina (Benigno \& Quebral, 1977). Gejala penyakit diplodia pada tanaman alpukat tampak pada batangnya namun yang muncul hanya pada dua tanaman saja. Diduga hal yang mungkin terjadi karena inokulum cendawan ini sudah mati sebelum masuk dan berkembang lebih lanjut kedalam jaringan tanaman.

Lima tanaman lain yang diuji dalam penelitian ini tidak menunjukkan gejala diplodia yakni tanamana nangka, pepaya, belimbing, karet dan kelapa. Dari hasil isolasi dan identifikasi pada ke lima tanaman ini, tidak ditemukan adanya cendawan $B$. theobromae. Hal ini menunjukkan bahwa kelima tanaman tersebut tidak dapat diserang oleh $B$. theobromae.

Pada sebuah literatur menyebutkan bahwa diplodia juga menyerang tanaman pepaya dan kelapa (Aicaf, 1995), tetapi pada penelitian ini tidak ditemukan adanya gejala diplodia setelah dilakukan isolasi dan identifikasi. Ada beberapa kemungkinan yang bisa menyebabkan hal tersebut, yaitu $B$. theobromae menyerang pada tanaman itu, tetapi tidak menimbulkan gejala pada batangnya, mungkin saja pada buah, daun atau bunganya. Pada tanaman pepaya, $B$. theobromae ini merupakan penyakit pascapanen yang menyebabkan busuknya buah dalam pengangkutan dan penyimpanan (Aicaf, 1995). Hal tersebut di atas juga kemungkinan terjadi pada kelapa. Kemungkinan lain adalah inokulum patogen ada dan masuk ke dalam jaringan tanaman, tetapi perlu masa 
inkubasi yang panjang untuk menimbulkan penyakit karena menurut Assuah et al. (2001) di Ghana, gejala diplodia baru muncul 18 bulan setelah inokulasi pada "rough lemon". Kemungkinan lain adalah ke lima tanaman itu bukan inangnya sehingga patogen tidak dapat menyerang ke lima tanaman tersebut.

Gejala awal tanaman dan perkembangan penyakit sangat dipengaruhi oleh faktor lingkungan seperti suhu, kelembaban, cahaya, unsur hara dan tanah. Faktor lingkungan juga sangat berpengaruh terhadap kerentanan dan ketahanan inang terhadap perkembangbiakan dan aktivitas patogen serta terhadap interaksi antara inang dan patogen, yang selanjutnya akan sangat berpengaruh terhadap munculnya gejala penyakit (Agrios, 1997).

Dengan diketahuinya jenis-jenis tanaman inang lain dari patogen penyebab penyakit kulit diplodia, maka dalam melakukan pengendalian disarankan untuk memperhatikan tanaman lain di sekitar pertanaman jeruk yang dapat menjadi inang alternatif bagi patogen.

\section{SIMPULAN} ini adalah:

Kesimpulan yang dapat diambil dari penelitian

1. Terdapat persamaan masa inkubasi patogen pada tanaman jambu monyet dan alpukat.

2. Disamping menyerang tanaman jeruk, $B$. theobromae juga dapat menyerang tanaman lain seperti jambu monyet dan alpukat, sehingga sumber infeksi selalu ada.

3. Gejala penyakit tidak muncul pada tanaman kelapa, nangka, belimbing, pepaya dan karet yang diuji kemungkinan besar dipengaruhi oleh masa inkubasi patogen yang panjang atau mungkin memang bukan inangnya.

\section{SANWACANA}

Penelitian ini merupakan bagian dari penelitian Fundamental. Penulis mengucapkan terima kasih kepada Direktorat Jenderal Penelitian dan Pengabdian kepada Masyarakat (DP2M), Dirjen Dikti, atas dukungan dananya.

\section{DAFTAR PUSTAKA}

Agrios, G.N. 1997. Plant Pathology. Academic Press.New York.

Aicaf. 1995. Diseases of Tropical Fruit Trees Association for International Cooperation of Agriculture and Forestry. Japan

Anonim, 2002. Proposal Kegiatan Penanggulangan Penyakit Diplodia sp Pada Tanaman Jeruk di KALSEL.(tidak dipublikasikan).

Anonim, 2005. Batola Jadi Lumbung Pangan Kalsel. Banjarmasin post. Senin 3 Januari 2005. http://www.indomedia.com/bpost/112004/21/bo rneo/trans7.htm. Diakses tanggal 7 Maret 2006.

Assuah, K.M; K.A. Oduro \& K.G. Ofoso. 2001. Diplodia natalensis Pole evans. The causal agent of citrus gummosis disease in ghana. Departemen of crop Science University of Ghana Legon. Ghana K.G.O.B. University of Ghana Agricultural Research Station Kade, Ghana.

http://www. Inasp. Info/ajol/journal/gjas/vol. 32 no. I abs. Diakses tanggal 23 Oktober 2004.

Balai Proteksi Tanaman Pangan dan Hortikultura Kalimantan Selatan. 2003. Laporan Tahunan Balai Proteksi Tanaman Pangan dan Hortikultura Tahun 2002/2003.

Barnett, H. L. \& B.B. Hunter. 1972. Illustrated Genera of Imperfect Fungi. Mineapolis: Burgress Publishing Co.

Benigno, D. R. A \& F. C. Quebral. 1977. Host Index of Plant Diseases In the Philippines. Coll. Agric., Univ Philippines, Los Banos.

Ohler, J.G. 1979. Cashew Cummunication 71 Departement of Agricultural Reseach. Amsterdam. 158-163. 
Olunloyo, O.A. \& O.F Esuruoso. 1975. Lastodiplodia theobromae floral shoot dieback disease of cashew in Nigeria. Plant Disease Reporter 59. 176-179.

Salamiah \& M. Melanie. 2004. Pengujian Kemampuan Tiga Macam Pestisida Botanis dalam Mengendalikan Penyakit kulit Diplodia Pada Jeruk. Unpublish.

Salamiah \& N. Rahmah. 2004. Pemanfaatan agens antagonis Trichoderma spp. dan Gliocladium untuk mengendalikan penyakiy kulit diplodia pada jeruk. Unpublish.
Semangun, H. 2000. Penyakit-penyakit Tanaman Hortikultura di Indonesia. Gadjah Mada University Press.

Setiawan, A. I. 1993. Usaha Pembudidayaan Jeruk Besar. Penebar Swadaya. Yogyakarta.

Sitepu, D. \& E.M. Adhi. 1990. Penyakit jambu monyet di Indonesia. Edisis Khusus LITTRO VI (2). 34-39.

Supriadi, E.M. Adhi, D. Sitepu, D. Febriyanti, \& N. Karyani. 1994. Identifikasi penyebab penyakit gumosis pada jambu monyet. Buletin Penelitian Tanaman Rempah dan Obat IX (1): 1-4. 